\title{
Mount Kenya: Discussion
}

Author(s): Halford Mackinder and Fowell Buxton

Source: The Geographical Journal, Vol. 58, No. 1 (Jul., 1921), pp. 21-25

Published by: geographicalj

Stable URL: http://www.jstor.org/stable/1780717

Accessed: 27-06-2016 08:47 UTC

Your use of the JSTOR archive indicates your acceptance of the Terms \& Conditions of Use, available at

http://about.jstor.org/terms

JSTOR is a not-for-profit service that helps scholars, researchers, and students discover, use, and build upon a wide range of content in a trusted digital archive. We use information technology and tools to increase productivity and facilitate new forms of scholarship. For more information about JSTOR, please contact support@jstor.org.

The Royal Geographical Society (with the Institute of British Geographers), Wiley are collaborating with JSTOR to digitize, preserve and extend access to The Geographical Journal 
phthisical; this led to my having a trained hospital assistant always in my parties.

During the last three expeditions numerous bearings were taken by prismatic compass, on the west, east, and south sides. On the last expedition the sources of seven rivers, the Nairobi, coming out of Lake Höhnel, the Nyamindi, Ena, Rupingazi, Thuchi and Ruguti, were discovered in springs or lakes below the precipitous faces of the ridge which forms the north and south wall. In the expedition of Igr 6 we found that it was the Nithi river which flowed down the Gorges valley, rising from springs at its head. A map was prepared for our expedition of February I920 by Major Kempthorne, Director of Topographical Surveys, which was accurate for all hills and rivers up to about 10,000 feet but not beyond. Major Kempthorne, assisted by Mr. Norman, has prepared a map based on Mr. Mackinder's original survey, but embodying the observations of this expedition; and this has been made the central portion of the War Office map of Mount Kenya, which is on the point of publication. The observations of August 1920, which have given considerably more information as to the hills, rivers, and valleys on the eastern side, were not available for this map, but these have been embodied by the Map Curator of the Royal Geographical Society in the map published herewith. The heights on the 1920 route are from readings of a mercurial barometer.

Before the paper the PREsident said : I have the pleasure to introduce to you Dr. Arthur, of the Scottish Mission in the colony of Kenya. He has spent many years in Kenya, and will describe to us this evening several attempts he has made to ascend Mount Kenya, and will also give us an account of that interesting colony.

\section{Dr. Arthur then read the paper printed above, and a discussion followed.}

The PRESIDENT : We shall be grateful to Sir Halford Mackinder, who is probably the only human being who has ever reached the summit of this mountain, if he will kindly give some account of his experiences.

Sir HALFORD MACKINDER : I should like in the first place to thank Dr. Arthur for the great pleasure he has given to me-probably more pleasure than to any one else in this room. I hardly know which it was that interested me most-the description of the mountain, when he called up memories of twenty-one years ago with every sentence, or the pictures of the present condition of the region through which you approach the mountain. I camped on the site of Nairobi before it existed, and you have seen the fine buildings there now. I think that gives some measure of the speed with which things have moved forward in Kenya Colony. Perhaps our greatest difficulty twenty-one years ago was in getting to the mountain at all. It was a time of famine; it was a time of small-pox; and the Uganda railway had only just reached the Athi plains. I was waiting for it to do so, because everybody who had been to the mountain before had been defeated by the fact that he had got fever into his bones, and I determined to rush the expedition, as far as possible, through the fever zone to the heights. By dint of great care we did it, but then we had to race away from small-pox, though even that we managed to keep clear of until 
nearly the end. When we were Io miles away from the railway we were already in unsurveyed and almost unknown country. Those Thika falls which have been shown to you were out in the wilds, and to-day there is a hotel beside them. Through the forest itself, of course, we had the same scenes that have been depicted on the screen just now.

May I congratulate Dr. Arthur on his perseverance in gathering scientific knowledge round this mountain? It is the way in which the science of geography must now grow-by people who settle beside some great physical feature and explore it thoroughly year after year, learning its climatic conditions, and so giving us finished geography, which we pioneers can only be thankful for and admire.

It is difficult to know exactly to what point to direct your attention, but it has occurred to me that if there are any Alpine clubmen present, as I dare say there are, their attention may have been caught by the observation made by Dr. Arthur just now, that it took my expedition three hours to get across that little glacier at the top. We called it the Diamond Glacier on account of its hardness. I may tell Dr. Arthur that during the past autumn his father called upon me and gave me a typewritten account of his son's last expedition-the expedition of August-and I found with great interest in that account that when Dr. Arthur was going away from the mountain, he saw through his glasses that the Diamond Glacier, instead of resembling the other glaciers in being covered with snow, was of green ice. We thought we could get across the Diamond Glacier when we first came near it in about twenty minutes. We found it intensely hard and very steep, and as it ended below in an overhanging cornice, we knew that an accident would probably be a fatal one. Therefore we had to cut pretty careful steps, because we knew we should probably have to come back through the afternoon storm. Every afternoon there was a wind and hailstorm on the peak, and it was well we took such care, because when we did come back it was through a driving cloud, and we had to clear the hail out of the steps. The ice was intensely hard, and up at 17,000 feet, even when in the fittest condition, it is not easy to work hard. But in addition to the mere height, we had no sheep to feed upon as had Dr. Arthur, and were living upon tinned provisions. I think Dr. Arthur said that in his experience the chief reason of mountain sickness was hard work. The particular kind of hard work which incapacitated me was digestion. I reached the summit because I took no solid food for thirty-six hours beforehand. I lived on meat lozenges, and by taking one every half-hour and going slowly, I got there.

I think, perhaps, I ought to mention that it was not one o'clock but twelve when César, Joseph, and I got to the top. I think it is important to correct that point, because I imagine that in Kenya Colony you will presently have an Alpine Club formed. They have one in South Africa, and the temptation is smaller there than in East Africa, where you have the magnificent peaks of Kilimanjaro, Kenya, and Ruwenzori. I should recommend the clubsmen to put a hut on to the south arête of Kenya. We spent the night up there. We could not carry heavy equipment up, and had to rope ourselves to the rock and grin and bear it. You must sleep at that height, because by twelve o'clock at the latest the cloud swirls round you. I gather from the accounts given by Dr. Arthur, and he made these ascents at two different periods of the year, that the régime of the weather was exactly the same as in the month I was there. You have the afternoon storm, and at sunset the sky clears. At ten o'clock at night, with the moon shining, the sight of the great peak above you is magnificent. The stars look like lamps in the black sky. All through the night it remains 
calm. In those valley heads it becomes very cold, and you get bottom ice formed in the streams. In the morning it remains beautiful, but somewhere between nine and twelve or one o'clock every day there comes up a hailstorm accompanied sometimes by thunder. You ought to be back on the arête, having been to the top, before that comes on. We were not back in time, but I should not advise anybody to tempt Providence again, and the peak can easily be achieved with a proper Alpine equipment provided you spend the night on the arête in comfort and you have luck in finding the glacier in a practicable condition.

Just one word as to names. Batian and Nelion were Masai chiefs. When I was out there the great plains, which are now covered with farms, were of course vacant. When I camped where is now Nairobi, out of the dead-level plain within a mile or so would browse a herd of three or four thousand mixed game. The Masai then wandered over those plains, and were still to a large extent masters of the region that had been theirs-nomads driving cattle-but it was already evident that they were doomed, because the white man was coming, and would want those great prairies for his farms. He would want labour, but it would be the labour of cultivators such as the Kikuyu. The Masai, although cruel, were a fine race. They thought of their god as dwelling on the peaks of Kenya, and I felt it was right that a memorial of the noble savage should there go down to history. The hero chiefs of the Masai two or three generations before the white man came were Batian and Nelion, two brothers it was said. Lenana was the living chief of the Masai at the time I was in East Africa. We took with us two Masai, and they carried Lenana's knobkerry by way of a passport in case we met any Masai out on the warpath. Tereri and Sendeyo were names of other Masai chiefs. Point Thomson was named after Mr. John Thomson, the photographer to this Society. My colleague, Mr. Campbell Hausburg, was, I believe, the first explorer to bring back to this country pictures in colour photography, and Mr. John Thomson took great trouble in arranging the apparatus, making all the preparations for that experiment, and that point was named after him by way of a thankoffering.

I will only refer to one other matter. We took no natives higher than Io,000 or II,000 feet to sleep. Our top camp was at I3,800 feet. The natives used to come up in the middle of the day and bring our stores up, and go down to sleep at 10,700. I found that they soon broke down in the higher altitudes. They got pneumonia, and that apparently was the experience in the various expeditions of Dr. Arthur. As a consequence we found it was necessary to travel absolutely light. Our anxiety was to secure the condition and equipment of an Alpine party for that last thousand feet, and yet to face the rough and tumble of a month's travelling through untamed tropical conditions. The way it was done was by taking out forty boxes packed in this country, hermetically sealed, each weighing twenty-five pounds. Of course we had no horses. It was all walking and human porterage. Each tin box contained all that a white man would want for six days, even down to matches and toilet requisites. Those forty boxes saved us. We travelled through a country in a state of famine with the natives at war with one another. They ambushed some of my men and killed two of them. The forest was inhabited by a people that Dr. Arthur has not spoken of - not quite dwarfs but nearly so. The Masai are nomads, the Kikuyu till the ground, but the Nderobbo are hunters in the depths of the forest. We never saw them; we never could establish relations with them, and yet they were always watching us. We slept in the starlight and moonlight, 
watched. When we left a camp in the Kenya forest, if we had occasion to go back ten minutes after, the empty tins were all gone. Towards the end, when I had sent away a considerable number of our porters because I could not feed them, we were unable to move our supplies without making double journeys. Having made the first journey we went back to fetch the remainder of our stores ; everything had been looted with the exception of the tin boxes, and they remained. I suppose the Nderobbo came to the conclusion that they could not open them, or perhaps did not even realize that they were boxes. Those boxes saved us to the end. The whole secret of our success was that we travelled light on the heights, having concentrated foods. We went round the mountain twice at high levels. That cairn which you saw on the top of Lenana was put up by Mr. Hausburg and César and Joseph. I had to go down to the foot of the mountain, and they spent the time on a photographing round. I went the second round with the two guides, and we spent three days at heights of about I 5,000 feet, making a plane-table survey of the mountain. We had to carry our plane-table and also our firearms, because we did not know what we should meet. We could not carry much weight in the way of food, and we could not carry a tent, but we could light fires of groundsel, and so we lived out in the open. I found no difficulty in breathing at the very top, but I am inclined to think that the conditions under the equator are perhaps not quite the same as elsewhere. I thought at the time that the hardness of the Diamond Glacier was due to the fact that it was mainly formed of hail. Whymper, in his account of the equatorial Andes, speaks also of the intense hardness of the glaciers when you get to the great heights. I ought finally to say that we could easily have climbed the second peak, Nelion, but the storm was coming on, and we did not think it worth while to risk our lives further.

Sir Fowell BuXton : I have no qualifications, either as a geographer or as a mountaineer, to be on the platform now, but I was Dr. Arthur's companion on the last occasion he attempted to climb the mountain. What I should like to say is in connection with the porters who carried our tents and supplies up -that it is largely due to Dr. Arthur's work amongst those people that they were willing to go with us at all. They are not mountain people. Few, if any, of them had lived at a higher altitude than the lower edge of the forest, but the very valuable medical and educational work that Dr. Arthur and his colleagues have done amongst these people has won for him their confidence and affection, and I think the fact that on so many occasions he has been able to organize these expeditions is very largely due to the personal tie between him and them. I believe that an audience like this will join with me in hoping that after so many attempts, he may one day succeed in reaching the top of the mountain.

The PRESIDENT : It is a wonderful thing that everywhere a European goes, if he sees a mountain, and especially if it is a pretty stiff one, he immediately tries to get to the top of it. This mountain has been standing in the middle of Central Africa for perhaps millions of years, and yet the inhabitants of those regions have in all probability never attempted to ascend it. It was not until some white men went there that men not only attempted but succeeded in reaching the summit. We congratulate Sir Halford Mackinder in having achieved that great feat-for it must be a great feat, as we realize when we see the tremendous difficulty of the rock climbing. We must also join with Sir Halford Mackinder in congratulating Dr. Arthur on having done such valuable work in filling in the geography of that region, making us better and better acquainted with the mountain, its slopes, glaciers, and rivers. One of the great difficulties must have been in the way of getting porters to accompany the 
expedition. A single mountain rising up in the middle of a plain, carries on it no mountain peoples like there are in the Himalaya, Andes, and Alps ; only a plains people are available, with bare feet, to go into what, to them, must have been terrible regions. It was doubtless due to the personal ascendency which Dr. Arthur had established over these people, and the affection he had instilled into them, that he was able to get them to follow him into those high regions. I am sure you will wish me to thank Dr. Arthur for having given us this interesting account and the valuable information about that region, and for his excellent slides, and will join with Sir Fowell Buxton in hoping that eventually he may be able to accomplish his ambition and get to the top.

\title{
PRESENT-DAY CONDITIONS IN SPITSBERGEN
}

\author{
J. M. Wordie
}

Read at the Meeting of the Society, 2 I March I921.

$\mathrm{N}$ the opinion of the writer the thorough scientific exploration of an unfamiliar region-especially within the polar circles where the navigating seasons are so short-entails continual work throughout at least three seasons. Of these the first can then be devoted to reconnoitring the broad features of the country; in the second the main spade-work of detailed investigation can be carried out; the third can be usefully occupied in the filling up of gaps and in revision of the more difficult problems. The explorations on which the present paper is based were made during a seven weeks' trip to Spitsbergen in the summer of I9r9, and one of four months' duration in the summer season of r920. A third visit would be desirable to round off the work, but, in the mean time, it is possible to speak with some assurance of the present-day conditions and of the geological history of that interesting island.

I propose to describe in some detail the two areas in Spitsbergen which I know best, Prince Charles Foreland and the lands round Stor fiord. The economic exploitation which has been the feature of the local history of the last few years has altered certain other parts almost beyond recognition. A description of Spitsbergen to-day would therefore be incomplete without some account of these developments in mining activity.

\section{Prince Charles Foreland.}

The Scottish Syndicate at whose instance the work was undertaken had intended that I should devote last summer (1920) as far as possible to Stor fiord ; but as that inlet is not navigable with safety before August, arrangements were made to spend the first few weeks of the season on Prince Charles Foreland. This was in some respects unfortunate, as the season at the latter place is much later than farther east in Ice fiord, and exploration was much handicapped in consequence.

The persistence of the giacier covering of Spitsbergen and of the 